\title{
STUDENTS' PERCEPTION ON THE DESIGN OF ASYNCHRONOUS ONLINE DISCUSSION USING SCHOOLOGY IN ENGLISH LANGUAGE EDUCATION GANESHA UNIVERSITY OF EDUCATION
}

\author{
Dewi, G. P. R. \\ English Language Education, Universitas Pendidikan Ganesha \\ rustikadewi93@gmail.com \\ Adnyani, L. D. S. \\ English Language Education, UniversitasPendidikanGanesha \\ surya.adnyani@undiksha.ac.id \\ Piscayanti, K. S. \\ English Language Education, UniversitasPendidikanGanesha \\ sonia_piscayanti@yahoo.com
}

\begin{abstract}
This study was aimed at investigating students' perception on the design of asynchronous online discussion using Schoology. This study was a case study research. The data in this study were collected quantitatively and qualitatively by using observation, questionnaire, and interview guide. The observation was conducted toward the design of asynchronous online discussion implemented by 2 lecturers in ICT and Poetry courses. The questionnaire was administered to one hundred students of English Language Education, Ganesha University of Education who were taught using Schoology in academic year 2017/2018. The interviews were done toward six students. The result of this study showed that 1) the design of the asynchronous online discussion in ICT and Poetry courses was different in terms of flexibility of time, flexibility of place, instruction or guidance, and topic, 2) the students had positive perception on the design of asynchronous online discussion.
\end{abstract}

Keywords: asynchronous design, perception, Schoology

\section{INTRODUCTION}

The development of technology and internet provides new method in the area of language teaching and learning. As the opportunities offered by this development, many higher education institutions adopt e-learning techniques (Su, Bonk, Magjuka, Liu \& Lee, 2005). Nowadays, trend in education requires the integration of technology and internet, since E-learning tecniques support the implementation of distance learning in higher education.

The integration of online mode of learning and traditional classroom also requires platforms or media in its practice. Learning Management System (LMS) is a type of weblogs that supports the integration of online mode of learning and traditional classroom (Hrastinski, 2008). Features in Learning Management System (LMS) supports administration, documentation, tracking, reporting program, classroom and online events, e-learning program, as well as training content (Ellis, 2009). It enables the educators to implement variety of online activities which support the education.

There are variety of Learning Management Systems that are commonly used in education. Schoology is one of Learning Management Systems whose features enable the educator to combine both traditional classroom and online learning. Features in Schoology allows indirect communication between the instructor and the students to update their statues, share links, pictures, and other media while the other students can give comments or just like the post (Ardi, 2017). Shoology provides instructional tools which enable the instructors to set a small group discussion. Type of dicussions that can be conducted by using Schoology is asynchronous online discussion, since it is conducted in non-real time setting. According to Hrastinski (2008), asynchronous online discussion is defined as students-students indirect 
communication through web-based tools such as e-mail, blogs, forums, and Learning Management System (LMS). In designing online discussion, there are several points that should be considered namely 1) setting up clear direction, 2) setting up the deadline, 3) setting up the issue that the students interest in and make the issue becomes the topic of the discussion (Rose and Smith, 2007).

In conducting asynchronous online discussion, the instructors have to pay attention on the plan how the asynchronous online discussion is designed. How the instructor design the discussion is an important aspect that influences students' learning. In designing asynchronous online discussion, the instructors have to maximize the benefit of Schoology as the learning platform and asynchronous online discussion itself in order to conduct an effective asynchronous online discussion.

Asynchronous online discussion in Schoology is commonly conducted as the supplement of the classroom meeting. Based on the preliminary interview conducted by the researcher, English Language Education (ELE) is one of study programs in Ganesha University of Education in Singaraja that conducts asynchronous online discussion using Schoology. Several lecturers admitted that they utilized Schoology as the learning platform to conduct asynchronous online discussion.

Based on the preliminary interview conducted by the researcher toward the lecturers, they revealed the reasons of conducting asynchronous online discussion is to solve the problems in learning process which deal with limitation of time. They also stated that they will conduct asynchronous online discussion every semester. It can be inferred that some lecturers in English Language Education (ELE), Ganesha University of Education implement asynchronous online discussion in their courses, since the lecturers admitted the benefit of asynchronous design of online discussion.

Hazari (2014), defined that perception is a complex mental concept that involves the attention paid to the material and previous experience. People interpret the stimuli into something meaningful based on their prior experiences. In terms of language teaching and learning, classroom environment is usually measured in terms of students or teacher perception. Students' perception includes their thought, belief, and feeling about person, situation, and event in the classroom (Hazari, 2014). Regarding to the fact that perception toward the learning process is an important concern that influences students' attitude, it is important to investigate students' perception. According to Perdanawati, (2010), the students have tendencies to create their own perception about the quality of learning and then give positive or negative reaction based on their own expectation and previous experience.

Before this present study, there were several relevant studies that had been conducted previously. Fayer (2014) conducted a study a multi-case study research which explored student's perception of online course design elements and success. Krasnova\&Ananjev (2015) had conducted a study about student's perception of learning in the online discussion environment. They investigated students' perception by analyzing students' attitude and expectation of learning in online discussion environment. Fedynich, Bredley and Bredley (2015) examined graduate students' perception of online learning. This study surveyed 249 students. In addition, Krause, Portolese, \& Bonner (2017) conducted a study about students' perception of the use of multimedia for online course communication. In this study, Krause, Portolese, \& Bonner explored how the students experienced the use of multimedia in both online announcements and discussions. Istifci (2017) investigated about perceptions of Turkish EFL students on online language learning platforms and blended language learning.

Compared with the previous studies, this present study and those previous studies investigate students' perception on learning in online-integrated environment. Meanwhile, the investigation of students' perception on the design of asynchronous online discussion is not the main concern that was investigated in the previous study. Since the benefit of asynchronous online discussion was highlighted, it is important to investigate the students' perceptions on the design of asynchronous online discussion using Schoology in English Language Education in order to design an asynchronous online discussion which is effective for students' learning.

This study was aimed at investigating (1) the design of asynchronous online discussion conducted by using Schoologyin ICT and Poetry courses, (2) students' perception on the design of asynchronous online discussion using Schoology.

Theoretically, this study was expected to be reference for further related studies about asynchronous online discussion. Practically, the result of this study can be used by lecturers in designing an effective asynchronous online discussion for students. The lecturer can conduct asynchronous online discussion which can meet students' expectation in order to maximize students learning. 


\section{METHOD}

The design of this present study was a case study research in order to investigate students' perception on the design of asynchronous online discussion. This study also analyzed the design of asynchronous online discussion conducted by using Schoology in English Language Education. Observation was employed in order to explore how the design of asynchronous online discussion. Meanwhile, interview, and questionnaire were used to obtain data about students' perception on the design of asynchronous online discussion.

The observation was conducted toward two different courses which conducted asynchronous online discussions. It was implemented by two different lecturers. In order to investigate the students' perception, this study surveyed one hundred students of English Language Education who were taught using Schoology in which online discussion took place. In addition, the interview related to the students' perception toward the implementation of asynchronous online discussion was conducted to six students.

The analysis of the data was done to the result of the observation, questionnaire and the result of the interview. The data from the questionnaire were processed in Microsoft Office Excel. The mean score and percentages of scale value of each items were counted. The students' perception was determined by categorizing the mean scores based on the qualification of level guideline suggested by Koyan (2012 pp 24-25). The very high categorization corresponds to very positive perception, while the lowest categorization corresponds to very negative perception. The analysis of the interview result used four steps of systematic activities suggested by Miles \&Huberman (1994). It consists of data collection, data reduction, data display, and conclusion drawing and verification.

\section{FINDINGS AND DISCUSSION Findings}

The observation was done toward the design of asynchronous online discussion which was implemented by using Schoology in ICT (Information and Communication Technology) and Poetry lecture. Students' perception on the design of asynchronous using Schoology in English Language Education was obtain by calculating the mean score of four dimensions in the design of asynchronous online discussion.

\section{The Design of Asynchronous Online Discussion}

The observation on the design of asynchronous online discussion was conducted toward ICT and Poetry courses handled by two different lecturers. The analysis of the design of asynchronous online discussion was done toward the flexibility of time, flexibility of place, instruction/guidance, and topic dimensions.

The first component that was analyzed was flexibility of time in the design of asynchronous online discussion. The findings showed that there were variety of time allocation set up by the lecturers who handled ICT and Poetry courses. In ICT course, the lecturer set a week time allocation for each section. In a section, the discussion was opened on February $19^{\text {th }}$ and the due date was set on February $26^{\text {th }}$. It showed that the students were given a week time allocation to do the discussion. On the other hands, the students in Poetry course were given one or two days time allocation to do the discussion. The discussion section was posted from April $19^{\text {th }}$ to April $20^{\text {th }}$.

The second component that was analyzed was flexibility of place. Regarding to the analysis of flexibility of place in asynchronous online discussion, the finding showed that the discussion is conducted both inside and outside the classroom meeting. It was proven by the discussion section conducted in ICT course. The students were instructed that the discussions were required in the classroom in a section. The other sections were conducted outside the classroom. In Poetry course, all discussion sections were conducted outside the classroom.

The third component that was investigated was instruction or guidance. In ICT course, the lecturer posted detail instructions about what the students need to do in the discussion. The instructions covered the due date, the task that the students need to accomplish, how the task should be done, and the rules in the discussion. In a section, the students were asked to do SWOT (Strengths, Weaknesses, Opportunities, and Threats) analysis on the use of ICT in Indonesian education. They were asked to work individually. The rules which were set up by the lecturer were not to repeat, be unique and autonomous, and give 
response to a minimum of three other students' work. Meanwhile, in Poetry course, the instructions or guidance only covered the due date, task, and how it should be accomplished.

The fourth component of the design of asynchronous online discussion was topic. The topics discussed in each section were different. In ICT course, the topics posted by the lecturer were continuous from one week to the next week. The topic given in certain week was still closely related to the last week's topic. For example, in topic 2 the lecturer posted about emerging technology. Then, in topic 3 the students were asked to discuss about integrating ICT-based media for teaching reading. On the other hands, Poetry course focused on analyzing poems and producing poems.

\section{Students' Perception on the Design of Asynchronous Online Discussion}

The students of English Language Education had positive perception on the design of asynchronous online discussion. It was obtained from the calculation of the data which were covered in 17 items. In the design of asynchronous online discussion, there were four dimensions investigated, such as flexibility of time, flexibility of place, instruction/guidance, and topic. The average of all items value was 48, 97 . The mean score was in interval 46, $75 \leq \mathrm{M}<55,25$ based on the categorization of mean score. It corresponded to positive perception. This result was supported by the interview result in which the respondents perceived the dimensions in design category positively.

Table 1. The Questionnaire Result of Students' Perception on the Design of Asynchronous Online Discussion using Schoology

VALUE OF EACH DIMENSIONS (\%)

\begin{tabular}{lcccc}
\hline \multicolumn{1}{c}{ DIMENSIONS } & SA & A & D & SD \\
\hline Flexibility of time & 17,2 & 57 & 23,8 & 2 \\
Flexibility of place & 20 & 55 & 23,5 & 1,5 \\
Instruction/guidance & 18,6 & 54,4 & 22,2 & 4,8 \\
Topic & 15 & 53,67 & 28,33 & 3 \\
\hline
\end{tabular}

Table 2. Interview Coding of Students Perception on the Design of Asynchronous Online Discussion

INTERVIEW CODING

\begin{tabular}{|c|c|c|}
\hline TRANSCRIPTIONS & Compacting Facts & Interpretations \\
\hline $\begin{array}{l}\text { "I like it. If the range of time is a week, i can do } \\
\text { anything else first. Then, the discussion in } \\
\text { another day, not in the same day." (r6;m) }\end{array}$ & Flexibility of time & $\begin{array}{l}\text { Positive perception on the } \\
\text { time allocation }\end{array}$ \\
\hline $\begin{array}{l}\text { "I am more comfortable outside the class. It is } \\
\text { because it is very noisy in the class, some } \\
\text { students play games. So, i cannot focus. I think } \\
\text { it is more comfortable at home." (r1;f) }\end{array}$ & Flexibility of place & $\begin{array}{c}\text { Prefering discussion } \\
\text { which is done outside the } \\
\text { classroom }\end{array}$ \\
\hline $\begin{array}{l}\text { "I do like it. Sometimes, if we are not given } \\
\text { clear instrutions, everybody has their own } \\
\text { interpretation toward what we are going to do. } \\
\text { When the instruction is already clear, } \\
\text { everything that we are going to do is already } \\
\text { written there. So, we can have one } \\
\text { interpretation about it." (r2;f) }\end{array}$ & Instruction/guidance & $\begin{array}{l}\text { Positive perception on the } \\
\text { clear instructions }\end{array}$ \\
\hline $\begin{array}{l}\text { "I prefer continuing the topic in the classroom. } \\
\text { For example, the topic is not yet finished to be } \\
\text { discussed or we do not understand the lecturer's } \\
\text { explanation, we can ask it in online discussion } \\
\text { to make us more understand." (r5;m) }\end{array}$ & Topic & $\begin{array}{l}\text { Prefering continuing the } \\
\text { topic which had been } \\
\text { dicussed } n \text { the classroom }\end{array}$ \\
\hline
\end{tabular}


Table 1 showed the comparison of percentage of students' perception on design of asynchronous online discussion using Schoology. Based on table 1, the students perceived the design of asynchronous online discussion positively. It was proven by the percentage of students' perception in each dimension which were over than 50 percent in 'agree' scale. All four dimensions that were investigated and analysed had the highest percentage on 'agree' scale, while 'strongly disagree' got the lowest percentage. It showed that most of the students had positive perception on the design of asynchronous online discussion using Schoology.

Table 2 showed the coding of interview result conducted toward R1, R2, R5, and R6. R1 stated that she felt more comfortable to do the discussion outside the classroom, since the situation in the classroom is not conducive to do asynchronous online discussion. R2 added her opinion about the instruction in the design of asynchronous online discussion. She stated that she liked a clear instruction or guidance in asynchronous online discussion in order to avoid multi-interpretation toward the instruction. R5 said that he preferred to continue the topic in the classroom in asynchronous online discussion, since he wanted to get clarification if there was something that he did not understand in the classroom meeting. R6 commented that the time allocation given by the lecturer was beneficial for him. He added that seven days time allocation enables him to do another thing first. It means that the time allocation allowes the students to do the discussion everytime which fits their schedule.

\section{Discussion}

Regarding to the findings, the design of asynchronous online discussion using Schoology in English Language Education was different in ICT and Poetry courses handled by different lecturers. This finding was supported by the theory proposed by Johnson (2013). Johnson states that the instructor need to purely facilitate the learning environment by creating a learning environment that engages and motivates the students to learn. Mellard (2006) states that the instructor has abilities to foster engagement learning activities or discussion. This statement support the finding that leacturers' ability in fostering their own online discussion make the design of every asynchronous online discussion is defferent.

Students' perception on the design of asynchronous online discussion was investigated by using four dimensions. All dimension was perceived positive by the students of English Language Education. First, the result of the questionnaire showed that the students of English Language Education had positive perception on flexibility of time. This finding was supported by Cerniglia (2011) who said that timeliness in written communication strategy in asynchronous online discussion makes the students feel valued and explicitly ask questions. The theory was also supported by the empirical study conducted by Krasnova\&Ananjev (2015). In their study, the students were given 1 week to do discussion. 95, 6 percent believed that time allocation was enough and 4,4 percent want the time allocation to be extended.

Second, flexibility of place was perceived positive by the students of English Language Education. The result of the interview also supported the statement above. The result of the interview toward respondent 1 showed that she was more comfortable doing discussion outside the classroom. It was supported by the result of empirical study conducted by Krasnova\&Ananjev (2015). According to them, asynchronous online discussion is said facilitates communication beyond the classroom.

Third, the result of the questionnaire showed that the students of English Language Education had positive perception on the instruction or guidance in the design of asynchronous online discussion. It was supported by the empirical study by Beckett, Amaro-Jiménez, and Beckett (2010) who stated that students need clear instructions in order to know how the task should be done or completed.

Fourth, the students of English Language Education had positive perception on topic in the design of asynchronous online discussion. The respondents had positive perception on the topic of the discussion. This result was supported by the result of previous empirical study conducted by Krasnova\&Ananjev (2015). It was stated that there is a tendency of the students to have more interesting and relevant issue for discussion.

\section{CONCLUSION}

Based on the findings and discussion, it can be concluded that; (1) the design of asynchronous online discussions implemented in ICT and Poetry courses were different in terms of flexibility of time, flexibility of place, instruction/guidance, and topic, (2) the design of online discussion was perceived 
positively by the students of English Language Education. The students perceived all dimensions in the design of asynchronous online discussion positively.

Regarding to the result of the study, there are several suggestions offered from this study. Firstly, it is suggested for other researchers who are interested to investigate related topic in online-integrated field. The result of this study can be used as a supporting reference for the related research to extend the scope of the study in terms of object of study, participants, or even the design of the study. Secondly, the result of this study suggests the lecturers to conduct asynchronous online discussion in their courses, since the students had positive perception on the design of asynchronous online discussion.

\section{REFERENCES}

Ardi, P. (2017). Promoting learner autonomy through schoology m-learning Platform in an EAP Class at an Indonesian university. Teaching English with Technology, 17(2), 55-76.

Beckett, G., Amaro-Jiménez, C., and Beckett, K. (2010). Students' use of asynchronous discussions for academic discourse socialization, Distance Education, 31(3), 315-33.

Cerniglia, E. G. (2011). Modeling best practice through online learning: Building relationships. YC Young Children, 66(3), 54-56, 58-59.

Ellis, R.K. (2009). Field Guide to Learning Management Systems, ASTD Learning Circuits. Retrieved fromhttp://www.astd.org/NR/rdonlyres/12ECDB99-3B91-403E-9B15 7E597444645D/23395/ LMS fieldguide 20091.pdf

Fedynich, L., Bradley, K.S., Bradley, J. (2015). Graduate students' perception of online learning. Research in Higher Education Journal, 27.

Fayer, L. Dr. (2014). A multi-case study of student perceptions of online course design elements and success. International Journal for the Scholarship of Teaching and Learning, 8(1).

Hazari, A. (2014).Learning Curve: student perceptions have a huge impact on understanding. Retrieved fromhttp://www.scmp.com/lifestyle/family-education/article/1407745/learning-curvestudent-perceptions-have-huge-impact

Hrastinski, S. (2008). Asynchronous and synchronous e-learning. Educause Quarterly, 31(4). 51-55.

Istifci, I. (2017). Perceptions of Turkish EFL students on online language learning platforms and blended language learning. Journal of Education and Learning, 6(1), 113-121.

Johnson, B. (2013). How do we know students are engaged? Edutopia. Retrieved from https://www.edutopia.org/blog/student-engagement-definition-ben-johnson

Koyan, I. W. (2012). Statistikpendidikanteknikanalisis data kuantitatif. Singaraja: Undiksha Press.

Krasnova, T., Ananjeva, A. (2015). Students' perception of learning in the online discussion environment. Mediterranean Journal of Social Sciences, 6. 202-207.

Krause, J., Portolese, L., \& Bonner, J. (2017). Student perceptions of the use of multimedia foronline course communication. Online Learning, 21(3), 36-49.

Mellard, D. D. (2006). Feasibility of explicit instruction in adult basic education: Instructor-learner interaction patterns. Adult Basic Education, 16, 21-37.

Miles, M. B., \&Huberman, A. M. (1994). Qualitative Data Analysis. Thousand Oaks: Sage.

Perdanawati, H. (2010). StudiKomparasiantaraPersepsiSiswaTentangKualitasPembelajaran IPS danIntensitasPenggunaanSumberBelajardenganPrestasiBelajar IPS SiswaKElas VIII di SMP Negeri 2 Surakarta tahunPelajaran 2009/2010 (Doctoral dissertation, UNS).

Rose, R., \& Smith, A. (2007). Chapter 9 Online discussions. In C. Cavanaugh \&R.Blomeyer (Eds.), What works in k-12 online learning (pp. 143-160). Washington, D.C.: International Society for Technology in Education.

Su, B., Bonk, C.J., Magjuka, R.J., Liu, X \& Lee, S.H. (2005). The importance of interaction in webbased education: a program-level case study of online MBA courses. Journal of Interactive Online Learning, 4(1), 1-19. 